\title{
PELAKSANAAN PROGRAM TRAINING EFL (EDUCATION FOR LIFE) DALAM MENINGKATAN PROFESIONALITAS GURU MENGGUNAKAN KONSEP DEMING
}

\author{
Imroatin Octaviarnis \\ Universitas Negeri Malang, Jalan Semarang No. 5 Malang \\ Email: octavia.amura@gmail.com
}

\begin{abstract}
The purpose of this study was to determine the implementation of the EFL training program in increasing the professionalism of teachers by using Deming's concept. The method used was descriptive qualitative. Data collection used interview methods and documentation. The researcher used the Deming cycle, namely PDCA (Plan-Do-Check-Act). Plan, the school principal identified the problems that occur through School Self Evaluation. Then, the principal made a draft about the provision of training and the criteria to be achieved. Do, the principal in collaboration with supervisors in determining the type of training needed was tailored to the needs. Check, the principal evaluated and monitored the training program. Act, the principal evaluated and followed up on training.
\end{abstract}

Keywords: Implementation, Training, Teacher Professionalism, and Deming's Concept

Abstrak: Tujuan penelitian ini adalah untuk mengetahui pelaksanaan program pelatihan EFL dalam meningkatkan profesionalitas guru dengan menggunakan konsep Deming. Metode yang digunakan adalah deskriptif kualitatif. Pengumpulan data menggunakan metode wawancara dan dokumentasi. Peneliti menggunakan siklus Deming yaitu PDCA (Plan-Do-Check-Act). Plan, kepala sekolah mengidentifikasi permasalahan yang terjadi melalui Evaluasi Diri Sekolah. Kemudian, kepala sekolah membuat rancangan tentang pengadaan pelatihan dan kriteria yang ingin dicapai. Do, kepala sekolah bekerjasama dengan supervisor dalam menentukan jenis pelatihan yang diperlukan disesuaikan dengan kebutuhan. Check, kepala sekolah mengevaluasi dan memonitori program pelatihan. Act, kepala sekolah mengevaluasi dan menindak lanjuti pelatihan.

Kata kunci: Pelaksanaan, Pelatihan, Profesionalisme Guru, dan Konsep Deming

\section{PENDAHULUAN}

Kualitas merupakan suatu keunggulan yang memiliki sesuatu unik dan terbaik. Kualitas juga dapat dilihat dari betapa bagus dan bermanfaatnya sesuatu tersebut. Ada empat pakar utama kualitas dalam Total Quality Management yaitu Crosby, Deming, Juran, dan Feiganbaum. Crosby (1979), quality is adjusted to standardized products. Deming (1986), quality is conformity with market requirements. Juran (1993), quality is the use of products tailored to market needs and customer satisfaction. Feiganbaum (1986), quality s overall satisfaction. Kualitas tidak hanya mengacu pada produk tetapi juga cara produk disajikan kepada pelanggan. Kualitas juga perlu adanya perbaikan secara berkelanjutan. Sederhananya, kualitas merupakan sebuah konsep yang telah dipandang sebagai proses yang berfokus pada pelanggan, yang membutuhkan perbaikan terus-menerus untuk memenuhi kebutuhan pelanggan.

TQM is a philosophy and set of guilding principles that represent the foundation of a continuosly improving organization. Tujuan dari TQM adalah untuk kepuasan pelanggan melalui peningkatan berkelanjutan. Kepuasan pelanggan adalah hasil akhir dari TQM. Adapun prinsipprinsip TQM menurut Wani dan Mehraj (20l4) yaitu long-term perspective, customer focus, and top management commitment, system"s thinking, training and tools in quality, increased employee participation, development of a measurement and reporting system, improved communication 
between management and labor, and continuous improvement. Sederhanaya, fokus TQM yaitu pada peningkatan berkelanjutan dan alat dan teknik/metode yang digunakan.

TQM juga dapat digunakan sebagai acuan untuk meningkatkan kualitas salah satunya adalah SDM. Menurut WEF (World Economy Forum) 2018 yang berjudul Human Resource Forum, Indonesia menduduki nomer 65 tentang kualitas SDM dari 130 negara. Berdasarkan indikator yang dipakai Indonesia berada pada peringkat 65. Kualitas SDM Indonesia masih dibawah negara ASEAN seperti Singapore peringkat 20, Malaysia peringkat 24, dan Thailand peringkat 55. Laporan tersebut menggambarkan seberapa kualitas SDM pada tiap-tiap golongan umur melalui 4 indikator yaitu capacity (kemampuan bekerja berdasarkan buta huruf dan pendidikan), deployment (tingkat partisipasi pekerja dan tingkat pendidikan), development (tingkat partisipasi pendidikan), dan know-how (tingkat pengetahuan dan kemampuan pekerja serta kesediaan sumber daya). Berkaitan dengan hal tersebut pemerintah telah melakukan sejumlah upaya dalam meningkatkan SDM salah satunya melalui pendidikan.

Dalam rangka meningkatkan kualitas SDM, diperlukan salah satu kompetensi yang harus dimiliki oleh guru adalah kompetensi professional. Guru dikatakan profesional apabila (I) Menguasai materi, struktur, konsep, dan pola pikir keilmuan yang mendukung mata pelajaran yang diampu, (2) Menguasai standar kompetensi dan kompetensi dasar mata pelajaran/bidang pengembangan yang diampu, (3) Mengembangkan materi pembelajaran yang diampu secara kreatif, (4) Mengembangkan keprofesionalan secara berkelanjutan dengan melakukan tindakan reflektif, (5) Memanfaatkan teknologi informasi dan komunikasi untuk berkomunikasi dan mengembangkan diri (BSNP, 2007).

Guru yang profesional merupakan guru yang mampu untuk mengelola dirinya sendiri dalam melakanakan tugas sehari-hari. Hal tersebut juga di dukung oleh pernyataan dari Rice dan Bishoprick (197I), Professional teachers are the teachers who are able to manage themselves in carrying out daily tasks. Menurut Bafadal (2008), profesionalisme guru merupakan proses dari ketidak tahuan (ignorance) menjadi tahu, dari ketidakmatangan (immaturity) menjadi matang, dari diarahkan oleh orang lain menjadi mengarahkan diri sendiri. Sedangkan menurut Glickman (198I), someone would be said professional, if he has the ability and motivation. Maksudnya adalah seseorang akan bekerja secara profesional apabila memiliki kemampuan dan motivasi yang tinggi. Sebaliknya, jika seseorang tidak bekerja secara profesional apabila tidak memenuhi persyaratan tersebut. Untuk menjadi guru yang profesional biasanya akan mengahadapi berbagai macam masalah.

Berbagai macam masalah tersebut juga terjadi di berbagai sekolah salah satunya adalah SD Kristen Kalam Kudus. Di SD Kristen Kalam Kudus ada beberapa masalah yang terjadi terkait dengan profesionalisme guru diantaranya adalah guru tidak linier, guru tidak cakap dalam mengajar, kurangnya motivasi, guru tidak melewati tahap orientasi, dan tidak ada program training untuk guru baru. Untuk mengatasi masalah tersebut perlu adanya dukungan yang dapat berpengaruh dengan profesionalisme guru. Salah satu bentuk dukungan dari sekolah terkait dengan profesionalisme guru adalah training.

Program pelatihan dalam suatu organisasi adalah proses di mana seseorang diajarkan dengan keterampilan dan diberi pengetahuan untuk melaksanakan tanggung jawab mereka dengan standar yang diperlukan dalam pekerjaan saat ini dan untuk melakukan peran yang lebih besar dan lebih menuntut untuk kinerja kerja yang efektif. Menurut Omar (20l4), Training program in an organisation is a process by which people are taught with skills and given the necessary knowledge or attitude to enable them to carry out their responsibilities to the required standard in the present job and to undertake greater and more demanding roles for effective job performance. Dengan adanya pelatihan, guru akan mendapatkan pengetahuan baru, ide, keterampilan dan sikap. Hal tersebut harus dikembangkan melalui cara yang terintegrasi dan sistematis yaitu melalui pelatihan di sekolah. 
Menurut Marsha \& Naftaly (1999), salah satu komponen penting untuk meningkatkan kualitas pendidikan adalah melalui pelatihan dalam jabatan bagi para guru. Sehubungan dengan ini, meskipun ada banyak layanan program pelatihan yang telah diselenggarakan oleh Departemen Pendidikan, dan Kantor Pendidikan Kabupaten, tetapi efektivitas pelatihan di sekolah tidak boleh dianggap enteng oleh manajemen sekolah dan juga guru.

Terdapat pro dan kontra pada penelitian sebelumnya yang mana menganalisis tentang peningkatan profesionalisme guru melalui program training Menurut Bașaran dan Karakurt (2017), trainings should be given to enhance proficiencies and competencies of all classroom and branch teachers as well as pre-service teachers, participation in such trainings should be encouraged. Disisi lain dengan adanya training dapat mentransfer motivasi dari pemateri ke audience. Menurut Gegenfurtner at al (2009 there is relationship with motivation to transfer during training process. Sedangkan, terdapat bantahan yaitu training does not appear to have improved teacher's commitment to teaching and educational equity (Rappaport et al, 2019). Oleh karena itu, peneliti ingin menganalisis pelaksanaan program training EFL (Education For Life) dalam meningkatan profesionalitas guru menggunakan konsep Deming.

\section{METODE}

Penelitian ini bertujuan untuk menganalisis program training guru di SD Kristen Kalam Kudus Malang. Penelitian ini tidak memberikan treatment (perlakuan), akan tetapi, untuk mengungkap data yang ada sehingga penelitian ini menggunakan rancangan penelitian deskriptif kualitatif. Variabel dalam penelitian ini adalah pelaksanaan program training EFL (education for life) dalam meningkatan profesionalitas guru. Pengumpulan data menggunakan metode wawancara dan dokumentasi. Selanjutnya, wawancara digunakan untuk mendapatkan data yang diinginkan disesuaikan dengan pedoman wawancara dan dilakukan kepada pihak kepala sekolah. Dokumentasi disini, peneliti menggunakan EDS, SPM, dan foto sebagai informasi pendukung. Peneliti menggunakan siklus Deming yaitu PDCA (Plan-Do-Check-Act).

\section{HASIL DAN PEMBAHASAN}

\section{Profil SD Kristen Kalam Kudus Malang}

Peneliti akan mengemukakan laporan hasil penelitian yang berkaitan dengan keadaan dilapangan, lokasi di SD Kristen Kalam Kudus Malang. Dengan uraian ini nantinya diharapkan akan dapat gambaran mengenai lokasi penelitian yang jelas serta dapat mengetahui data yang akan diangkat. Berdasarkan hasil penelitian itulah maka dapat diperoleh hal-hal sebagai berikut. SD Kristen Kalam Kudus yang terletak di Jl. Arief Margono No. 18, Kasin, Malang. SD swasta ini memiliki visi yaitu Terbangunnya manusia utuh yang takut akan Tuhan, mandiri dan berguna bagi dunia. Misi SD Kristen ini adalah Mengajak peserta didik untuk memiliki hati yang takut akan Tuhan, Membimbing peserta didik supaya mengasihi sesama manusia, menghargai lingkungan ciptaan Tuhan, Membina peserta didik bertumbuh menjadi manusia yang sehat mental, berbudi pekerti luhur dan bertanggung jawab sesuai nilai kebenaran, Memberikan pengetahuan yang berkualitas kepada peserta didik sesuai tuntutan perkembangan jaman, Melengkapi peserta didik dengan ketrampilan yang berkualitas sesuai kebutuhan dan potensi untuk perkembangan dirinya, dan Memberdayakan setiap stakeholder (semua yang berkepentingan) untuk menjadi insan pendidikan. 


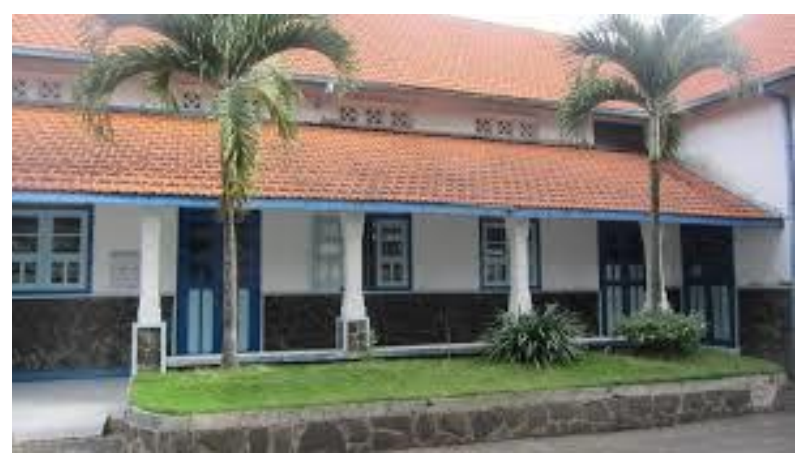

Gambar I SD Kristen Kalam Kudus Malang

2. Deskripsi dan Analisis Data Pelatihan Profesionalisme Guru di SD Kristen Kalam Kudus Malang

\section{Deskripsi dan Analisis Data}

Guru atau pendidik di SD Kristen Kalam Kudus Malang berjumlah 42 orang. Untuk mengetahui secara rinci dan jelas tentang jumlah guru atau pendidik yang ada dilihat pada tabel berikut :

\begin{tabular}{|c|c|c|c|}
\hline No & INDIKATOR & KRITERIA & $\begin{array}{l}\text { JUMLAH } \\
\text { (Orang) }\end{array}$ \\
\hline \multirow[t]{8}{*}{ I } & \multirow[t]{8}{*}{ Kualifikasi Pendidikan Guru } & $<=$ SMA Sederajat & \\
\hline & & DI & \\
\hline & & D2 & \\
\hline & & D3 & \\
\hline & & SI & 41 \\
\hline & & S2 & I \\
\hline & & S3 & 0 \\
\hline & & Jumlah & 42 \\
\hline \multirow[t]{3}{*}{2} & \multirow[t]{3}{*}{ Sertifikasi } & Sudah & 6 \\
\hline & & Belum & 36 \\
\hline & & Jumlah & 42 \\
\hline \multirow[t]{3}{*}{3} & \multirow[t]{3}{*}{ Gender } & Pria & 6 \\
\hline & & Wanita & 36 \\
\hline & & Jumlah & 42 \\
\hline \multirow[t]{5}{*}{4} & \multirow[t]{5}{*}{ Status Kepegawaian } & PNS & \\
\hline & & GTT & \\
\hline & & GTY & 42 \\
\hline & & Honorer & \\
\hline & & Jumlah & 42 \\
\hline \multirow[t]{9}{*}{5} & \multirow[t]{9}{*}{ Pangkat / Golongan } & II a & \\
\hline & & $\mathrm{II} \mathrm{b}$ & \\
\hline & & II c & \\
\hline & & II d & \\
\hline & & III a & \\
\hline & & III b & \\
\hline & & III c & \\
\hline & & III d & \\
\hline & & IV a & \\
\hline
\end{tabular}




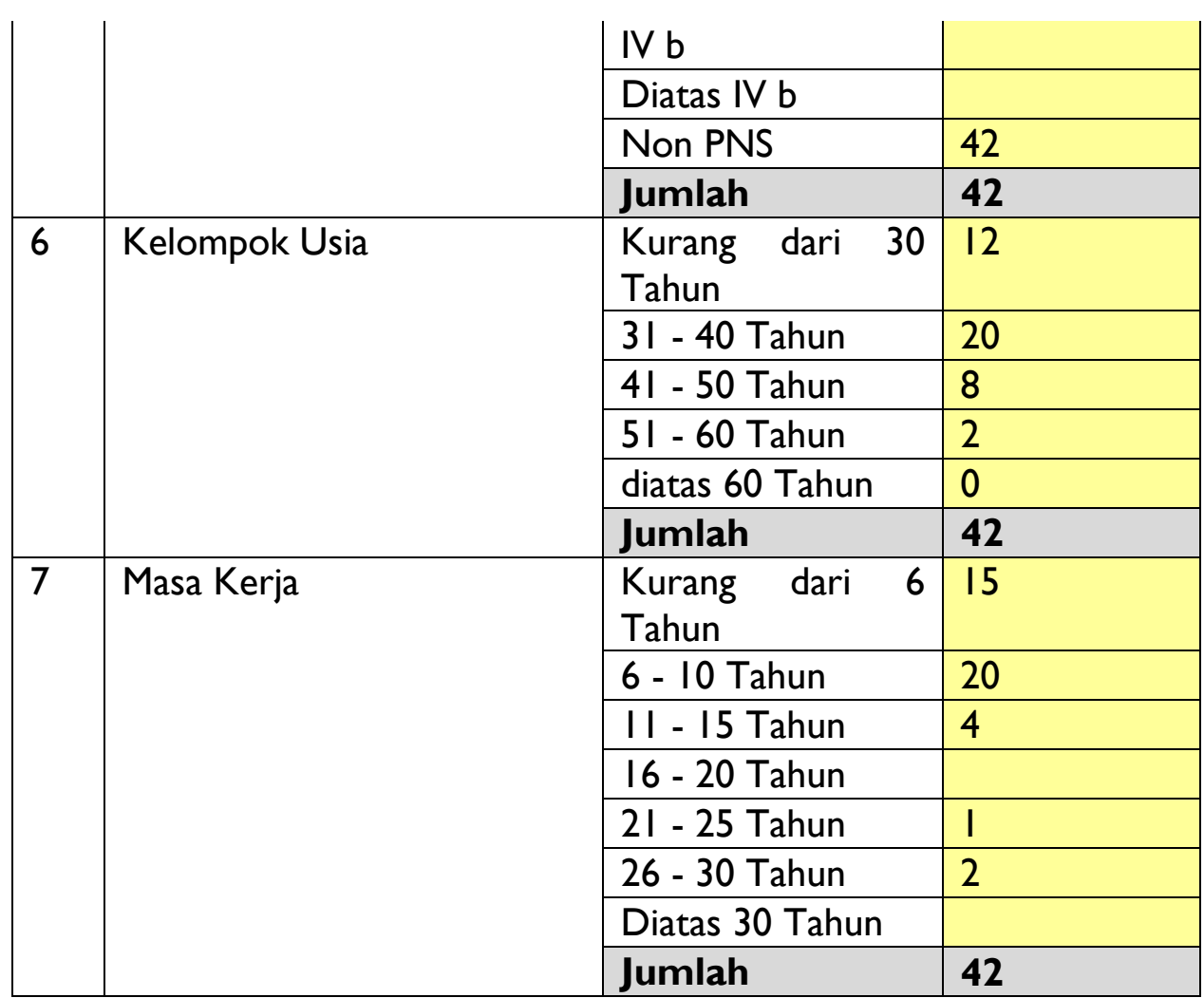

Tabel I Sumber: Dokumentasi SD Kristen Kalam Kudus Malang

Kualifikasi tenaga pendidik merupakan syarat minimal sebagai tenaga pendidik karena guru yang sudah memiliki kualifikasi berarti sudah mempunyai kemampuan dan keterampilan yang lebih dalam meningkatkan kompetensinya. Pada pengembangan profesionalisme guru kualifikasi sebagai tenaga pendidik merupakan kebutuhan utama yang harus dimiliki guru karena kualifikasi tenaga pendidik adalah pemenuhan dalam jangka yang panjang dimana kebutuhankebutuhan lain yang perlu dimiliki oleh guru dapat dipenuhi melalui kegiatan-kegiatan yang berkesinambungan sesuai dengan kebutuhan yang diinginkan. Hal tersebut berdasarkan pernyataan kepala sekolah saat wawancara sebagai berikut :

"Iya untuk kualifikasi guru sudah berjalan dengan baik, 100\% guru yang mengajar sudah memiliki ijazah minimal SI. Akan tetapi, masih ada juga beberapa guru yang mengajar tidak sesuai dengan kualifikasi yang dimiliki. Adapun jika ada beberapa guru yang ingin meningkatkan kualifikasinya untuk lanjut studi diperkenankan dari sekolah, lanjut studi juga ada yang dari pemerintah dan ada juga yang dilakukan secara pribadi”

Berdasarkan data diatas, sekolah telah memiliki kualifikasi SI bahkan ada yang S2. Kondisi ini jelas sudah memenuhi syarat minimal seorang guru yaitu Strata I. Akan tetapi, berdasarkan hasil wawancara yaitu;

"Ada beberapa guru yang tidak sesuai dengan kualifikasi akademik yang dimiliki dengan mata pelajaran yang diampu. Dari 42 guru terdapat 9 orang guru yang mengajar tidak sesuai dengan kualifikasi yang dimiliki. Kondisi ini harus menjadi perhatian khususnya kepala sekolah untuk memotivasi guru sebagai tenaga pendidik guna meningkatkan kompetensi yang dimiliki. Meskipun ada beberapa guru yang memiliki kemampuan mengajar sudah memenuhi kualifikasi, tetapi masih terbatas sehingga perlu bimbingan dan pelatihan guna memperdalam wawasan serta keterampilan sehingga kompetensi yang dimiliki dapat terus meningkat. Selain itu, mengingat kepentingan-kepentingan individu guru masih perlu terus berkembang, maka perlunya pelatihan yang sangat bermanfaat untuk: (I) memberikan kesempatan bagi guru untuk mengembangkan pengetahuan sehingga mampu untuk mendewasakan diri, (2) keluar dari praktek lama, dan (3) meningkatkan produktivitas." 
Selain itu, kepala sekolah juga mengatakan bahwa;

"Upaya pelatihan yang dilakukan SD Kristen Kalam Kudus untuk mengembangan profesionalisme tenaga pendidik sudah cukup baik. Dari kegiatan pelatihan yang ada kegiatan sering diikuti adalah kegiatan pelatihan diluar sekolah dengan mengirimkan tenaga pendidik mengikuti Diklat, Workshop, pelatihan dari Diknas sesuai dengan jumlah peserta yang dibutuhkan dalam permintaan (undangan). Namun, terdapat juga pelatihan didalam sekolah yang diadakan setiap tiga bulan sekali. Program pelatihan tersebut merupakan program wajib yang diadakan oleh sekolah SD Kristen Kalam Kudus Malang dan diberi nama Education For Life (EFL). Semua guru diwajibkan hadir saat dimulainya pelatihan. Program Pelatihan EFL juga disesuaikan dengan keadaan yang dihadapi guru sehari-hari. Program tersebut telah berjalan selama dua tahun. Untuk saat ini, sekolah juga fokus dalam mengembangkan program tersebut. Adapun anggaran program pelatihan tersebut sudah masuk ke dalam anggaran sekolah."

Pelatihan tidak sebatas pelatihan formal akan tetapi juga meliputi kegiatan-kegiatan luas seperti yang dituturkan oleh kepala sekolah.

"kegiatan lain meliputi ceramah dan diskusi, kunjungan ke sekolah lain, praktek langsung dikelas dan lain sebagainya.

Kegiatan pelatihan yang diselenggarakan disekolah akan ditampilkan pada tabel berikut :

Peningkatan profesionalisme guru setelah diadakan pelatihan. Hal tersebut telah dipaparkan oleh kepala sekolah, yaitu;

"Terlihat peningkatan ya setelah adanya program pelatihan EFL tersebut. Meskipun peningkatan tersebut tidak dapat dilihat secara langsung. Setidaknya saat ini, guru yang tidak linier dengan bidang yang diajarnya dapat memahami materi yang akan diajarkanya dengan menggunakan metode yang dipaparkan saat pelatihan.

\section{Pelatihan Menggunakan Model Deming}

Pelatihan dengan menggunakan siklus Deming telah diterapkan di SD Kristen Kalam Kudus Malang. Akan tetapi, perlu adanya peningkatan dan perbaikan terus menerus. Berikut adalah gambar siklus Deming.

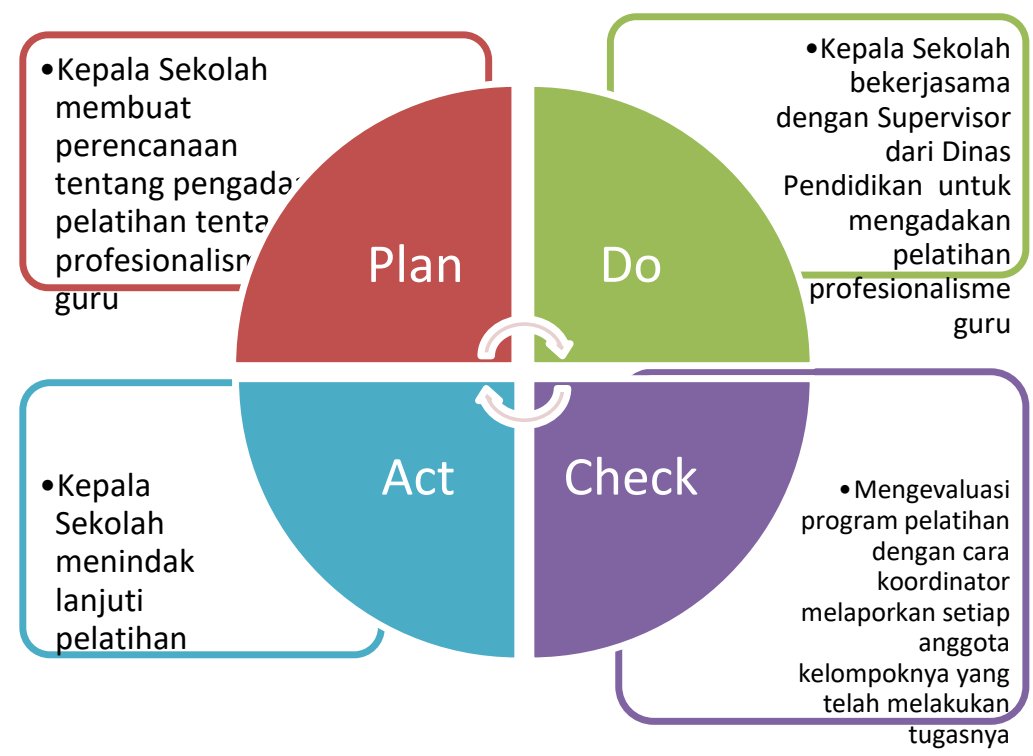

\section{Gambar 2 Model Pelatihan yang diadakan di SD Kristen Kalam Kudus Malang}

Langkah pertama yaitu Plan. Plan, kepala sekolah mengidentifikasi permasalahan yang terjadi terkait dengan profesionalisme guru melalui Evaluasi Diri Sekolah. Kemudian, kepala sekolah membuat rancangan tentang pengadaan pelatihan dan kriteria yang ingin dicapai. 
Langkah kedua yaitu Do, kepala sekolah bekerjasama dengan supervisor dalam menentukan jenis pelatihan yang diperlukan disesuaikan dengan kebutuhan. Selain itu, kepala sekolah juga mencari pelatih yang berpengalaman dalam melaksanakan pelatihan. Disisi lain, Kepala Sekolah juga melibatkan guru untuk menyediakan sarana dan prasarana dan SDM.

Langkah ketiga yaitu Check, kepala sekolah mengevaluasi program pelatihan dengan cara koordinator melaporkan setiap anggota kelompoknya yang telah melakukan tugasnya. Disamping itu, kepala sekolah juga memonitoring keadaan pelatihan sehingga dapat berjalan sesuai dengan rencana.

Langkah terakhir yaitu Act, kepala sekolah mengevaluasi dan menindak lanjuti pelatihan untuk memastikan efektifnya pelatihan secara terus menerus sehingga guru puas akan adanya pelatihan tersebut. Selanjutnya, hasil dari penilaian tersebut dapat diarsipkan dan didokumentasikan melalui foto maupun video.

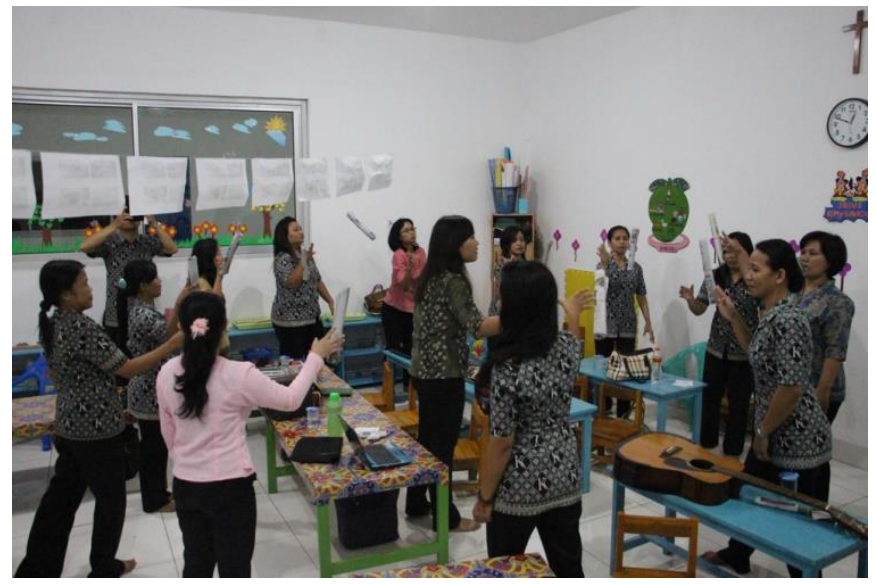

Gambar 3 Dokumentasi Pelatihan guru di SD Kristen Kalam Kudus Malang

\section{KESIMPULAN}

Setelah penulis mengadakan pembahasan dan analisa data, hasil penelitian yang penulis lakukan di SD Kristen Kalam Kudus tentang pelaksanaan pelatihan profesionalisme guru adalah sebagai berikut :

I. Program kualifikasi, dalam program ini guru di SD Kristen Kalam Kudus sudah memiliki kualifikasi yang dipersyaratkan oleh pemerintah berarti dalam hal ini sudah menunjukkan bahwa guru SD Kristen Kalam Kudus memiliki kompetensi yang baik, serta masih ada beberapa guru yang mengajar tidak sesuai dengan kualifikasi yang dimiliki.

2. Dalam program pelatihan, madrasah melakukan pengiriman terhadap tenaga pendidik ketika mendapat undangan pelatihan. Tidak hanya pelatihan diluar madrasah pun melaksanakan pelatihan didalam madrasah. Pelaksanaannya sesuai dengan langkah-langkah yang ada, mulai dari identifikasi masalah yang dihadapi guru sampai pada tindak lanjut dari kegiatan pelatihan.

3. Program Pelatihan menggunakan siklus Deming yaitu Plan-Do-Check-Act.

\section{DAFTAR PUSTAKA}

Bașaran, Semra dan Karakurt, Sevgi. (2017). Development and Evaluation of the Efficiency of Inservice Training Program with the Theme of Peace Education. Universal Journal of Educational Research 5(8): I425-1434, 2017 http://www.hrpub.org DOI: 10.13189/ujer.2017.050816 diakses pada 28 April 2019

Bafadal, Ibrahim. (2008). Peningkatan Profesionalisme Guru Sekolah Dasar Dalam Kerangka Manajemen Peningkatan Mutu Berbasis Sekolah. Jakarta: Bumi Aksara 
BSNP. (2007). Permen No. I6 Tahun 2007 tentang standar Kualifikasi Akademik dan Kompetensi Guru. Jakarta

Gegenfurtner, A., Veermans, K., Festner, D., \& Gruber, H. (2009). Integrative literature review: Motivation to transfer training: An integrative literature review. Journal of Human Resource Development Review, 8(3), 403- 423. https://www.futureacademy.org.uk/files/images/upload/44_4792_7638_fullText_I_28.p df diakses apada 28 April 2019

Marsha Botello, Naftaly S. Glasman, (1999) "Dimensions of teacher in-service training for school improvement", International Journal of Educational Management, Vol. I 3 Issue: I, pp. I4-24, https://doi.org/ I0.I 108/095 I35499/0253437

Omar, Che. (2014). The Need for In-Service Training for Teachers and It's Effectiveness In School Assoc. Faculty of Management and Economics Sultan Idris Education University. International Journal for Innovation Education and Research www.ijier.net Vol.2-II, 2014 International Educative Research Foundation and Publisher (C) 2014 pg. I file://C:/Users/Via/Downloads/26I-Article\%20Text-524-I-10-20170205.pdf diakses pada 28 April 2019

Peraturan Pemerintah Nomor 18 Tahun 2007 tentang Kompetensi Guru

Rappaport, Shelley. Somers, Marie. Dan Granito, Kelly. (2019). A Redesigned Training Program for New Teachers Findings from a Study of Teach For America's Summer Institutes. America: MDRC

Rice. G.H \& Bishoprick, D.W. (I97I). Conceptual Models of Organization. New York: Meredith Corporation

Wani, Iftikhaar dan Mehraj, Hakim. (20l4). Total Quality Management in Education: An Analysis. International Journal of Humanities and Social Science Invention ISSN (Online): 2319 - 7722, ISSN (Print): 2319 - 77/4 www.ijhssi.org Volume 3 Issue 6/| June. 20I4/| PP.7I-78 www.ijhssi.org 7I | P a g e

World Economy Forum. (2018). The Global Human Capital Report: Preparing People For The Future of Work. World Economy Forum 